Hardison, W. A. \& Reid, J. T. (1953). F. Nutr. 5r, 35.

Hardison, W. A., Linkous, W. N. \& Ward, C. Y. (1957). F. Dairy Sci. 40, 768.

Hoelzel, F. (1930). Amer. F. Physiol. 92, 466.

Hueper, W. C. (1941). Quoted by: Rennie, I. (1956). Proc. Nutr. Soc. 15, 6r.

Hydén, S. (1956a). LantbrHögsk. Ann. 22, 139.

Hydén, S. (1956b). LantbrHögsk. Ann. 22, 411 .

Kane, E. A., Jacobson, W. C. \& Moore, L. A. (1952). F. Nutr. 47, 263.

King, K. W. \& Moore, W. E. C. (1957). F. Dairy Sci. 40, 528.

Lambourne, L. J. (1957). F. agric. Sci. 48, 273.

Lancaster, R. J., Coup, M. R. \& Percival, J. C. (I953). N.Z. F. Sci. Tech. A, 35, I I7.

Moore, J. H. (1957). Brit. F. Nutr. I1, 273.

Oyaert, W. (1955). Studie van de wijziging der minerale en stikstofhoudende fractie van het voeder tijdens de passage doorheen de voormagen. Thesis, State University, Ghent.

Pigden, W. J. \& Brisson, G. J. (1956). Canad. F. agric. Sci. 36, 146.

Raymond, W. F. \& Minson, D. J. (1955). F. Brit. Grassl. Soc. 10, 282.

Schalk, A. F. \& Amadon, R. S. (1928). Bull. N. Dak. agric. Exp. Sta. no. 216.

Schürch, A. F., Lloyd, L. E. \& Crampton, E. W. (1950). F. Nutr. 4r, 629.

Shaffer, C. B. \& Critchfield, F. H. (1947a). Analyt. Chem. r9, 32.

Shaffer, C. B. \& Critchifield, F. H. (19476). F. Amer. pharm. Ass. Sci. Ed. 39, 340.

Shaffer, C. B., Critchfield, F. H. \& Carpenter, C. P. (1948). Amer. F. Physiol. 152, 93.

Sperber, I., Hydén, S. \& Ekman, J. (1953). LantbrHögsk. Ann. 20, 337.

Woodman, H. E. (1954). Bull. Minist. Agric., Lond., no. 48, I 3 th ed.

\title{
The amino-acid requirement of laying hens
}

\section{Minimal requirement levels of essential amino-acids: techniques and development of diet*}

\author{
By DEWEY JOHNSON, JR. AND HANS FISHER \\ Department of Poultry Science, Rutgers University, New Brunswick, New fersey
}

(Received 13 Fanuary 1958 -Revised 9 April 1958)

The objectives of previous studies from this laboratory were to develop a diet in which nitrogen was supplied as free amino-acids that would maintain egg production (Fisher \& Johnson, I956) and to determine those amino-acids essential for it (Johnson \& Fisher, 1956). In proceeding with the determination of the requirement for individual amino-acids it was necessary, in order to reduce all amino-acids to minimal levels, to consider the factors that influence the amino-acid requirement of a species.

$\mathrm{N}$ intake has been shown to influence the requirement of several amino-acids in diets containing protein. However, no direct information is available concerning the effect of the $\mathrm{N}$ intake as related to diets containing free amino-acids. The relationship between protein intake and caloric intake has been well established in chick nutrition and reports are beginning to appear concerning the relationship between dietary aminoacid level and energy intake.

* Paper of the Journal Series, New Jersey Agricultural Experiment Station, Rutgers University, the State University of New Jersey, Department of Poultry Science, New Brunswick.

Paper no. I: F. Nutr. (1956), 60, 26r. Paper no. 2: F. Nutr. (1956), 6o, 275. 
Wisconsin workers (Benton, Harper, Spivey \& Elvehjem, I956 $a, b$; Elvehjem, I956) have described various interactions of amino-acids when low-protein diets were fed to rats, indicating that low $\mathrm{N}$ intakes increase the sensitivity of rats to improper aminoacid balances.

Swendseid \& Dunn (1956) determined the isoleucine requirement of young women by giving them previously determined minimal levels of essential amino-acids. The results gave values somewhat lower for isoleucine than those obtained by Rose, Eades $\&$ Coon (I955) who gave abundant levels of essential amino-acids.

Nasset (1957) reported extremely poor performance of adult rats given an aminoacid mixture, based on levels of essential amino-acids that had been previously determined for maintenance of the adult rat, in diets containing an excess of all essential amino-acids but the single one under study. Two reasons are proposed for this poor performance: $(\mathrm{I})$ the diets had been made equal in $\mathrm{N}$ content by adding glutamic acid which changed the ratio of essential to non-essential amino-acids; (2) all amino-acids do not behave in the same way when the concentrations of the other amino-acids are changed.

In view of the complexity of these factors it becomes essential to select a point of departure for future experimentation. A diet containing minimal levels of essential amino-acids which maintains egg production should provide a fixed point from which parameters defining these factors can be formulated.

\section{EXPERIMENTAL AND RESULTS}

\section{General procedure}

As young pullets can be shifted from the practical to the purified diet with greater success than older hens, Single-comb White Leghorn pullets from the University flock in production for from 2 to 4 months and laying in clutches of two eggs or more were used in these studies. The details of the experimental procedure are given in a previous publication (Fisher \& Johnson, 1956). The diets contained maize oil $5 \cdot 00$, minerals (Fisher \& Johnson, 1956) 5.34, fibre $3 \cdot 00$, limestone $2 \cdot 5^{\circ}$, antacid absorbant (Fisher \& Johnson, I956) I.00, sodium bicarbonate $\mathrm{I} \cdot 00$, choline chloride $0 \cdot 10$, mixture of vitamin A, cholecalciferol and $\alpha$-tocopheryl acetate (Fisher \& Johnson, I956) ०.I0, vitamin mix (Fisher \& Johnson, 1956) O.I5, nitrogenous components as listed in Table I, and maize starch to $100 \%$. In the early experiments the level of ammonium citrate was varied to provide $2 \% \mathrm{~N}$ in all diets; this practice was abandoned when it became apparent that the hens did not require so much $N$. Certain experiments are presented in greater detail to describe important points. The original plan of experimentation was to reduce one amino-acid at a time until the minimum level was found that would maintain egg production. The amino-acid at this determined level was then incorporated into the diet and other amino-acids were studied in a like manner. Two criteria were employed to evaluate the diet: feeding trials of 2 weeks' duration and the $\mathrm{N}$ balance. The $\mathrm{N}$-balance technique proved a sensitive criterion of amino-acid adequacy and provided two additional advantages over the feeding trial: ( $\mathrm{I}$ ) a balance experiment could be completed in less time than required by a feeding trial; (2) $\mathrm{N}$ 


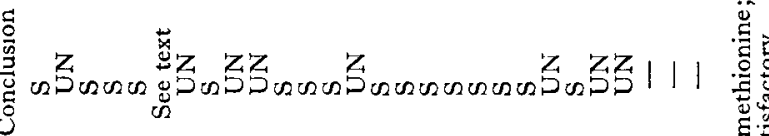

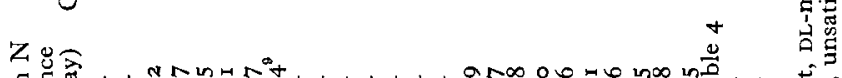
它

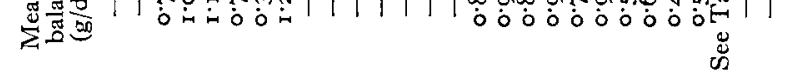
कo

:

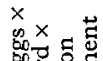

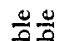

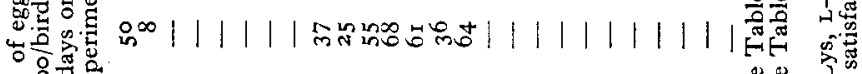
安总 ڤั้

.

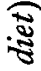

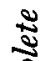

峞要 完量

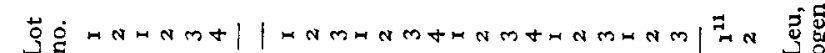

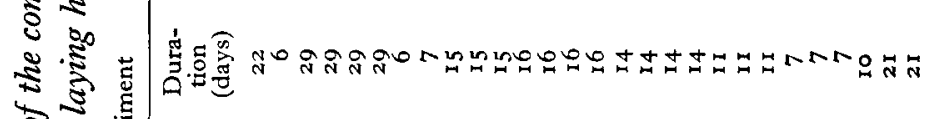
○一

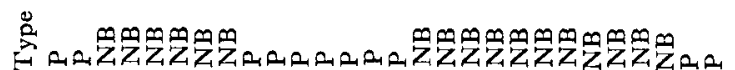

iें

| $\mid$

है।

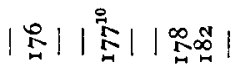

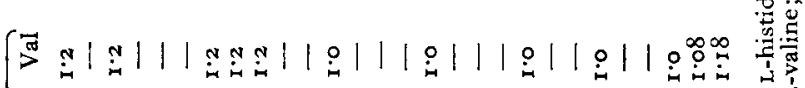

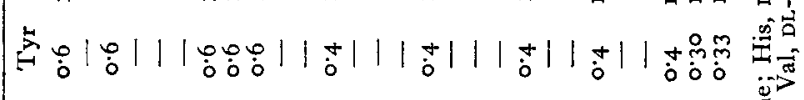

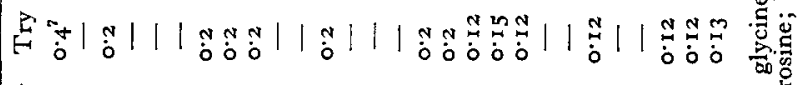

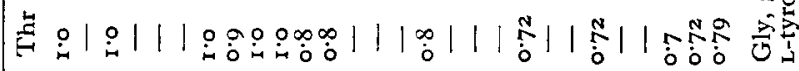

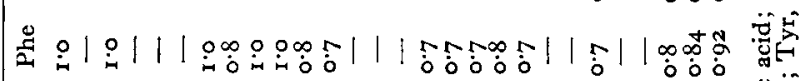

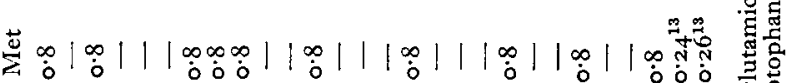

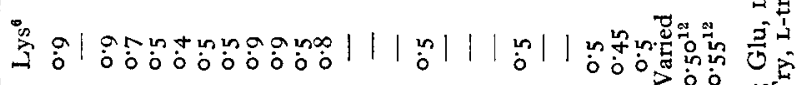

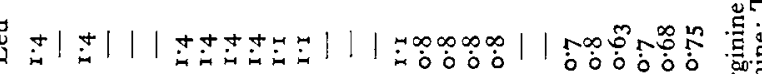


balance provides data of a continuous nature whereas egg-production records represent discontinuous functions.

Total $24 \mathrm{~h}$ collections were made. The excreta were quantitatively transferred to a blender with water and homogenized for 2 min. The mixture was then made up to $500 \mathrm{ml}$. in a volumetric flask and an appropriate portion taken for Kjeldahl analysis (Association of Official Agricultural Chemists, 1955). $\mathrm{N}$ balance in this sense includes the $\mathrm{N}$ required for egg production. An average egg $(55 \mathrm{~g})$ contains approximately $0.93 \mathrm{~g} \mathrm{~N}$.

Beginning with Exp. I75, the procedure of screening diets for $\mathrm{N}$-balance studies was standardized as follows: birds were placed on the diet 4 days before collection of excreta was begun for $N$ retention analysis. Birds were selected on the basis of their adequate food consumption for a 5-day balance study. During the first 2 days of the 5 -day period the birds received previously determined levels of amino-acids and for the remaining 3 days the test diet with the level of one or more amino-acids changed. As shown in Tables 2 and 3 , birds so treated responded immediately either to an impaired or an improved amino-acid mixture in the 3 days after the dietary change.

Since Mitchell (1950) had successfully used the 'ratio method' in determining amino-acid requirements for growth from the composition of carcass amino-acids, this approach was followed here for the relationship between egg-protein composition and amino-acid requirement for egg production. The amino-acid levels determined by this technique provided useful estimates of essential amino-acid levels to be tested in $\mathrm{N}$ balance as well as in production experiments.

\section{Feeding trials}

Attempts to reduce the content of isoleucine were made first because this aminoacid was present at a level approximately twice the published requirement based on protein studies (Miller, Sunde, Bird \& Elvehjem, 1954). Reduction of DL-isoleucine (see footnote 5 , Table $\mathrm{I}$ ) from $2 \cdot 0$ to $\mathrm{I} \cdot 6 \%$ of the diet resulted in immediate cessation of egg production by each of four hens (Exp. I63, Table 1 ).

Lysine was studied next because it was also present in a higher proportion relative to the known requirement based on protein studies (Ingram, Cravens, Elvehjem \& Halpin, $195 \mathrm{I}$ ). The $\mathrm{N}$ balance was used to evalute the performance of hens on graded levels of lysine. The results are summarized in Table I (Exp. I64) and presented in detail in Table 2. $\mathrm{N}$ retention was improved by the reduction in lysine content but decreased again at the lowest level given. In view of the improvement shown possible, the $0.4 \%$ level was judged unsatisfactory. Several times with L-lysine at the $0.5 \%$ level hens did not consume their diet properly and $\mathrm{N}$ balance or egg production was poor. A typical result is illustrated in Table I (Exp. $\left.{ }^{6} 65\right)$. This difficulty was overcome by lowering the content of threonine and phenylalanine (Table I, Exp. 168).

While experiments with isoleucine and lysine were in progress, separate trials were begun to determine the effect of lowering the level of histidine in the diet. Exp. I $7 \mathbf{I}$ (Table I) indicates that a reduction of histidine was possible if leucine, lysine, phenylalanine and threonine were simultaneously reduced. A further reduction was found possible after other changes had been made (see Table I, Exps. I76 and I82). 
Unexpectedly it became possible at this point to reduce isoleucine quite sharply, as illustrated in Exp. 174, lot I (Table I) and in all subsequent trials.

Exp. 174 was done to explore differences, if any, between glutamic acid, glycine and ammonium citrate as extra sources of non-essential $\mathrm{N}$. Lot I was given $r \cdot 36 \% \mathrm{~N}$, whereas lots $2-4$ received $2 \cdot 0 \% \mathrm{~N}$. The results indicate that with the higher $\mathrm{N}$ intake, the mixed source was superior to glutamic acid alone.

Table 2. Sensitivity of nitrogen balance to level of L-lysine in the diet of laying hens

\begin{tabular}{|c|c|c|c|c|}
\hline \multirow[b]{2}{*}{ Bird no. } & \multicolumn{4}{|c|}{$\begin{array}{c}\text { Mean values with their standard errors ( } \mathrm{g} / \text { day) for } \\
\text { nitrogen retention on diet with }\end{array}$} \\
\hline & $\begin{array}{l}0.9 \% \text { lysine } \\
\text { (I I) }\end{array}$ & $\begin{array}{c}0.7 \% \text { lysine } \\
\text { (8) }\end{array}$ & $\begin{array}{c}0.5 \% \text { lysine } \\
(4)\end{array}$ & $\begin{array}{c}0.4 \% \text { Iysine } \\
\text { (6) }\end{array}$ \\
\hline I & $0.67 \pm 0.05$ & $0.97 \pm 0.06$ & $0.92 \pm 0.11$ & $0.49 \pm 0.05$ \\
\hline 2 & $0.77 \pm 0.05$ & $1 \cdot 03 \pm 0.06$ & $I \cdot 13 \pm 0.02$ & $0.35 \pm 0.08$ \\
\hline 3 & - & $I .12 \pm 0.02$ & $1.27 \pm 0.10$ & $0.78 \pm 0.1 I$ \\
\hline 4 & - & $I \cdot 15 \pm 0.02$ & $1 \cdot 28 \pm 0.10$ & $I \cdot 04 \pm 0.14$ \\
\hline Mean & 0.72 & $1 \cdot 07$ & I'I 5 & $0.7 \mathrm{I}$ \\
\hline
\end{tabular}

Figures in parentheses are the number of days on the diet and hence the numbers of estimations.

Other modifications of the diet were made for Exp. 175 in which (I) leucine was drastically reduced (see Exp. I7I) and (2) a $60 \%$ reduction in tryptophan was shown to yield satisfactory results. In Exps. 176 and 177 further amino-acid reductions were studied as shown in Table $\mathrm{I}$.

With amino-acid levels found adequate in Exps. 176 and 177 , ratios with tryptophan as a base were calculated from the composition of whole-egg protein. Values determined for leucine and lysine were critically tested by the $\mathrm{N}$-balance technique at the estimated level against a 10\% reduction of this level. The results are shown in Table 3. It can be seen that the predicted requirement was adequate whereas a $10 \%$ reduction resulted in a marked decrease in $\mathrm{N}$ retention. Though little information could be

Table 3. Sensitivity of nitrogen balance in laying hens to deficiency of leucine or lysine defined by requirements estimated by 'ratio method' (see p. 279)

\begin{tabular}{|c|c|c|c|c|c|c|c|c|c|c|}
\hline \multirow[b]{3}{*}{$\begin{array}{l}\text { Day on } \\
\text { experimental } \\
\text { ration* }\end{array}$} & \multicolumn{5}{|c|}{ Leucine } & \multicolumn{5}{|c|}{ Lysine } \\
\hline & \multirow[b]{2}{*}{$\begin{array}{c}\text { Level } \\
\text { in diet } \\
(\%)\end{array}$} & \multicolumn{2}{|c|}{ Bird no. I } & \multicolumn{2}{|c|}{ Bird no. 2} & \multirow[b]{2}{*}{$\begin{array}{c}\text { Level } \\
\text { in diet } \\
(\%)\end{array}$} & \multicolumn{2}{|c|}{ Bird no. 3} & \multicolumn{2}{|c|}{ Bird no. 4} \\
\hline & & $\begin{array}{l}\text { No. of } \\
\text { eggs } \\
\text { pro- } \\
\text { duced }\end{array}$ & $\begin{array}{c}\mathrm{N} \\
\text { balance } \\
(\mathrm{g} / \text { day })\end{array}$ & $\begin{array}{l}\text { No. of } \\
\text { eggs } \\
\text { pro- } \\
\text { duced }\end{array}$ & $\begin{array}{c}\mathrm{N} \\
\text { balance } \\
\text { (g/day) }\end{array}$ & & $\begin{array}{l}\text { No. of } \\
\text { eggs } \\
\text { pro- } \\
\text { duced }\end{array}$ & $\begin{array}{c}\mathrm{N} \\
\text { balance } \\
(\mathrm{g} / \text { day })\end{array}$ & $\begin{array}{l}\text { No. of } \\
\text { eggs } \\
\text { pro- } \\
\text { duced }\end{array}$ & $\begin{array}{c}\mathrm{N} \\
\text { balance } \\
\text { (g/day) }\end{array}$ \\
\hline I & 0.70 & I & 0.90 & I & 0.96 & 0.50 & ○ & $1 \cdot 00$ & I & 0.92 \\
\hline 2 & 0.63 & o & 0.76 & o & 0.84 & 0.45 & I & 0.89 & $\circ$ & 0.86 \\
\hline 3 & 0.63 & I & 0.76 & I & 0.89 & 0.45 & $\circ$ & 0.88 & I & 0.79 \\
\hline 4 & 0.63 & $\mathbf{I}$ & ND & 0 & ND & 0.45 & 0 & ND & $\circ$ & ND \\
\hline 5 & 0.63 & $\circ$ & ND & $\mathbf{I}$ & ND & 0.45 & 0 & ND & I & ND \\
\hline 6 & 0.63 & I & 0.64 & $\circ$ & 0.52 & 0.45 & $\circ$ & 0.60 & $\circ$ & 0.75 \\
\hline 7 & 0.63 & I & 0.69 & o & 0.28 & 0.45 & I & 0.74 & 0 & 0.67 \\
\hline
\end{tabular}

ND, not determined.

* Birds received, as a percentage of the total diet, 0.70 leucine or 0.50 lysine 2 days before N-balance studies. 
obtained from the egg-production records during the experimental period, the sensitivity of $\mathrm{N}$ balance to border-line deficiencies was apparent for both amino-acids studied.

In view of these results an experiment was designed to study the lysine requirement more precisely in order to obtain a separate base value for calculating the essential amino-acid requirement of the laying hen. The results of this study (Table I, Exp. I78) are presented in detail in Table 4 . The $\mathrm{N}$ balance appeared to be stabilized at the level of $0.5 \%$ lysine. This value was now used in calculating the predicted requirements for the other essential amino-acids based on the composition of whole-egg protein. These predicted values are presented in Table 5 .

Table 4. Determination of the lysine requirement of laying hens with nitrogen retention as the criterion of adequacy

\begin{tabular}{ccccc} 
& \multicolumn{4}{c}{ Mean values (g/day) for nitrogen retention on diet with } \\
Replication* & $0.40 \%$ lysine & $0.45 \%$ lysine & $0.50 \%$ lysine & $0.55 \%$ lysine \\
I & 0.29 & 0.53 & 0.94 & 0.84 \\
2 & 0.56 & 0.74 & 0.72 & 0.73 \\
3 & 0.79 & 0.75 & 1.15 & 1.02 \\
Mean & 0.55 & 0.67 & 0.94 & 0.86
\end{tabular}

* Each replication represents one bird on each lysine level ; since replications were made against time, comparisons between lysine levels are valid only within each replicate.

Table 5. Amino-acid requirements of laying hens based on the composition of whole-egg protein and the lysine requirement (see this page above)

\begin{tabular}{|c|c|c|c|}
\hline \multirow[b]{2}{*}{ Amino-acid } & \multicolumn{2}{|c|}{ Whole egg } & \multirow{2}{*}{$\begin{array}{c}\text { Calculated } \\
\text { requirement } f \\
\text { (percentage of diet) }\end{array}$} \\
\hline & $\mathrm{g} / \mathrm{I} 6 \mathrm{~g} \mathrm{~N} \mathrm{~N}^{*}$ & Ratiof & \\
\hline Cystine & $2 \cdot 3$ & 0.33 & 0.16 \\
\hline Histidine & $2 * 4$ & 0.35 & 0.18 \\
\hline Isoleucine & $6 \cdot 9$ & I. 00 & 0.50 \\
\hline Leucine & $9 \cdot 4$ & $I \cdot 36$ & 0.68 \\
\hline Lysine & $6 \cdot 9$ & $(\mathrm{I} \cdot \infty)$ & $(0.50)$ \\
\hline Methionine & $3 \cdot 3$ & 0.48 & 0.24 \\
\hline Phenylalanine & $5 \cdot 8$ & 0.84 & 0.42 \\
\hline Threonine & $5^{\circ} 0$ & 0.72 & $0 \cdot 36$ \\
\hline Tryptophan & $I \cdot 6$ & 0.23 & 0.12 \\
\hline Tyrosine & $4 \cdot 1$ & 0.59 & 0.30 \\
\hline Valine & $7 \cdot 4$ & I.07 & 0.54 \\
\hline
\end{tabular}

In the final experiment of this series (Table $\mathrm{I}$, Exp. I 82) a diet containing the essential amino-acids at levels given in Table 5 together with L-arginine hydrochloride $0.9, \mathrm{~L}-$ glutamic acid 3.5 , glycine 0.5 , and ammonium citrate $0.5 \%$ was studied in terms of egg production and food consumption. Table 6 gives the results for this diet and also for a diet containing an additional $10 \%$ of each amino-acid. As minimal levels of aminoacids were given, the production record for the five hens on the estimated levels was surprisingly good during the 3 -week experimental period. The excellent production by 
four out of five hens on the estimated levels increased by only 10\% indicates that the objectives of the investigation had been reached. Thus, it would appear that minimal levels have been ascertained and that most hens will maintain good egg production on diets containing these estimated levels of essential amino-acids increased by I0\% (as a safety factor).

Table 6. Egg production and food consumption of laying hens on amino-acid diets containing the amino-acids at the estimated level of requirement (Table 5) or the estimated level increased by $10 \%$

\begin{tabular}{|c|c|c|c|c|c|c|c|}
\hline \multirow[b]{2}{*}{ Bird } & \multicolumn{3}{|c|}{ Estimated level } & & \multicolumn{3}{|c|}{ Estimated level $+10 \%$} \\
\hline & $\begin{array}{c}\text { Ist } \\
\text { week }\end{array}$ & $\begin{array}{l}\text { 2nd } \\
\text { week }\end{array}$ & $\begin{array}{c}3^{\text {rd }} \\
\text { week }\end{array}$ & Bird & $\begin{array}{c}\text { Ist } \\
\text { week }\end{array}$ & $\begin{array}{l}\text { 2nd } \\
\text { week }\end{array}$ & $\begin{array}{l}3^{\text {rdd }} \\
\text { week }\end{array}$ \\
\hline \multicolumn{8}{|c|}{ Egg production (eggs/week) } \\
\hline A & 3 & 2 & 5 & $\mathrm{~F}$ & 5 & I & 3 \\
\hline $\mathbf{B}$ & 3 & o & 0 & $\tilde{G}$ & 4 & 6 & 4 \\
\hline $\mathrm{C}$ & 3 & $\mathbf{I}$ & 2 & $\mathbf{H}$ & 4 & 5 & 5 \\
\hline $\mathrm{D}$ & 6 & 5 & 2 & $\mathrm{I}$ & 3 & o & 0 \\
\hline $\mathrm{E}$ & 5 & o & 2 & J & 5 & 4 & 5 \\
\hline Mean & 4.0 & $1 \cdot 6$ & $2 \cdot 2$ & Mean & $4 \cdot 2$ & $3 \cdot 2$ & $3 \cdot 4$ \\
\hline \multicolumn{8}{|c|}{ Food consumption (g/day) } \\
\hline A & 90 & 80 & $8 \mathrm{r}$ & $\mathbf{F}$ & 90 & 90 & 73 \\
\hline $\mathrm{B}$ & 73 & 73 & 77 & $\mathbf{G}$ & 89 & 77 & 68 \\
\hline C & $6 I$ & 70 & 82 & $\mathrm{H}$ & 96 & 84 & $9 \mathrm{I}$ \\
\hline D & 82 & 106 & 77 & $I$ & $(64)$ & (50) & (25) \\
\hline $\mathrm{E}$ & 52 & 69 & 72 & $\bar{J}$ & 91 & 86 & 86 \\
\hline Mean & 72 & 79 & 72 & Mean & $\begin{array}{l}86 \\
91\end{array}$ & $\begin{array}{l}77 \\
84^{*}\end{array}$ & $\begin{array}{l}69 \\
80^{*}\end{array}$ \\
\hline
\end{tabular}

* Mean when value in parentheses is omitted; from the beginning bird I never consumed enough food to stay in production.

\section{DISCUSSION}

This work shows that the amino-acid balance is very important in the protein nutrition of the pullet. Although it is very difficult to point to definite interactions between amino-acids, it can be stated that all amino-acids do not affect each other in the same manner. Lysine, for example, could be reduced to a minimal level in the presence of excesses of all the other amino-acids. Histidine could be reduced slightly at first, then, as the levels of the other amino-acids were also reduced, further reduction was possible. On the other hand, isoleucine could not be reduced at all until some of the other aminoacids (possibly leucine) were present at levels lower than in the initial diet of this series. The fact that there are so many possible combinations of amino-acids makes the problem of defining interactions very difficult. In this study, several changes were made simultaneously so that interactions of various amino-acids are difficult to point out except to recognize that they were present. Thus, Nasset's (1957) suggestion that amino-acids do not behave in the same way when the proportions of the remaining amino-acids are changed is supported by these results.

Since the final amino-acid diet contains minimal levels of essential amino-acids, it should prove a useful base to study the interactions or antagonisms that exist among amino-acids. 
To date no information is available concerning the relative proportions of essential and non-essential amino-acids required for protein formation. It is known that liberal supplementation with sources of essential or non-essential amino-acid $\mathrm{N}$ can have deleterious effects on the animal organism. The mechanisms of this inhibition have not been completely clarified. Exp. I74 (Table I) with hens receiving glutamic acid, glycine and ammonium citrate as sources of non-essential amino-acid $\mathrm{N}$ indicated that a combination of the three sources of $\mathrm{N}$ was more efficient than glutamic acid alone. Unpublished results from this laboratory with chicks indicate that with the amino-acid diet used in these experiments no advantage was obtained by adding ammonium citrate. Thus, experimental conditions can be obtained such that non-specific sources of $\mathrm{N}$ do not behave in the same manner.

Table 7. Effect of an amino-acid diet on the plasma-protein fractions of laying hens as separated by paper electrophoresis*

\begin{tabular}{|c|c|c|c|c|c|c|c|c|}
\hline \multirow[b]{2}{*}{ Diet } & \multirow[b]{2}{*}{$\begin{array}{c}\text { Bird } \\
\text { no. }\end{array}$} & \multirow{2}{*}{$\begin{array}{c}\text { Plasma } \\
\text { protein } \\
\text { (g/roo ml. })\end{array}$} & \multirow{2}{*}{$\begin{array}{l}\text { Albumin } \\
\text { (g/roo ml.) }\end{array}$} & \multicolumn{5}{|c|}{ Globulin $(\mathrm{g} / \mathrm{r} 00 \mathrm{ml}$.) } \\
\hline & & & & $\alpha_{2}$ & $\alpha_{3}$ & $\beta$ & $\gamma$ & PP \\
\hline Amino-acid $(1.5 \% \mathrm{~N})$ & $\begin{array}{l}557 \\
550\end{array}$ & $\begin{array}{l}4.4 \\
4.0\end{array}$ & $\begin{array}{l}0.45 \\
0.53\end{array}$ & $\begin{array}{l}0.45 \\
0.35\end{array}$ & $\begin{array}{l}0.33 \\
0.44\end{array}$ & $\begin{array}{l}0.67 \\
0.44\end{array}$ & $\begin{array}{l}I .47 \\
0.71\end{array}$ & $\begin{array}{l}0.33 \\
0.35\end{array}$ \\
\hline Mean & & $4 \cdot 2$ & 0.49 & 0.40 & 0.38 & 0.55 & I.09 & 0.34 \\
\hline $\operatorname{Practical}(2 \cdot 4 \% \mathrm{~N})$ & $\begin{array}{l}549 \\
546\end{array}$ & $\begin{array}{l}4 \cdot 4 \\
4.4\end{array}$ & $\begin{array}{l}0.94 \\
0.64\end{array}$ & $\begin{array}{l}0.31 \\
0.55\end{array}$ & $\begin{array}{l}0.62 \\
0.64\end{array}$ & $\begin{array}{l}0.94 \\
0.84\end{array}$ & $\begin{array}{l}0.52 \\
0.82\end{array}$ & $\begin{array}{l}0.42 \\
0.27\end{array}$ \\
\hline Mean & & 4.4 & 0.79 & 0.43 & 0.63 & 0.89 & 0.67 & 0.34 \\
\hline
\end{tabular}

* Fractions interpreted according to Vanstone, Maw \& Common (1955); PP, presumptive phosphoprotein.

The role of the $\mathrm{N}$ intake has received much attention with diets containing protein. By custom it has been the practice to include liberal supplies of protein in diets designed for egg production. Scattered experiments have shown that equally good egg production can be obtained with well-balanced low-protein diets(Carpenter, Duckworth \& Ellinger, 1954; Thornton, Blaylock \& Moreng, 1957). Though $\mathrm{N}$ balance has been maintained in man, and egg production maintained in the hen, over a considerable period on diets low in $\mathrm{N}$ derived from free amino-acids, the effects of $\mathrm{N}$ intake per se has not been investigated with these diets. Undoubtedly depletion of the protein reserves may occur when individuals are placed on diets in which low levels of $\mathrm{N}$ are supplied from amino-acids. The importance of these protein reserves in the laying hen has not been studied. That changes do occur on 'amino-acid' diets low in $\mathrm{N}$ is shown by a comparison of the values quoted in Table 7 for plasma-protein fractions, separated by electrophoresis, of hens given practical $(2 \cdot 4 \% \mathrm{~N})$ and 'amino-acid' $(\mathrm{r} \cdot 5 \% \mathrm{~N})$ diets. Again the significance of these changes must await further study.

Lysine was chosen to be the base from which to calculate the remaining essential amino-acid requirements because it does not take part in transamination reactions and has no known function other than protein synthesis. The lower egg production on the diet containing the calculated amino-acid levels was not unexpected because the values for all amino-acids were believed near a limiting level. If any one of these should be 
below the requirement for an individual hen little or no egg production would be expected. A slight increase of all the amino-acids gave excellent egg production by four hens. One hen did not consume enough of the diet from the very beginning to maintain production. This behaviour may be indicative of an amino-acid deficiency. If so, it would take a great deal of work to show which amino-acid or acids were deficient for this bird.

It must be remembered that all the amino-acid levels were calculated from the determined lysine requirement for egg production. This requirement includes both the requirements for egg production and for maintenance. If, for example, the maintenance requirement for any one amino-acid as a proportion of the total requirement should be greater than the proportion of lysine required for maintenance, the calculated total requirement would be too low. The sulphur-containing amino-acids might well be involved. Miller (1944) has shown that methionine is required in relatively greater amounts than other essential amino-acids during protein depletion.

The requirements for arginine and glutamic acid were not studied in these experiments. The concentration of glutamic acid was not changed because it was used to supply both essential and non-essential amino-acid N to the hens. Arginine was reduced to the value calculated from the composition of the egg protein and no further reduction was attempted. In chick nutrition these amino-acids appear to belong to the semiessential class of amino-acids and in all probability great variation may be encountered when a study of the requirement for these amino-acids is made. There are also problems concerned with the role of $\mathrm{N}$ intake in a diet that is limiting in total $\mathrm{N}$ that must be considered in a study of these amino-acids.

The requirements established in this study for lysine, tryptophan and isoleucine (Table 5) agree well with published requirements obtained with protein-containing diets (Ingram et al. I95 I Miller et al. I954). The first estimate of the leucine requirement (Cravens, I948) of the laying hen was not more than $1 \cdot 34 \%$ of the diet. This estimate was revised downward by Machlin (1955) to not more than $\mathrm{I} \cdot 0 \%$ of the diet. The present work shows that egg production can be maintained when leucine constitutes $0.7-0.8 \%$ of the diet. The methionine and cystine levels found adequate in the present study are somewhat lower than those recommended by the (USA) National Research Council (Bird, Almquist, Cravens, Hill \& McGinnis, 1954).

\section{SUMMARY}

I. Beginning from the free amino-acid diet for laying hens previously developed in this laboratory, a series of experiments was carried out to reduce all amino-acids to minimal levels for egg production.

2. Egg production and nitrogen retention were used as criteria of amino-acid adequacy.

3. It was observed that some amino-acids could not be reduced in the diet without also considering the balance for other amino-acids.

4. Minimal levels for the essential amino-acids were determined with the ratios of amino-acids to lysine in whole-egg protein as the basis for estimates. 
5. Levels of amino-acids thus determined were tested against these levels increased by $10 \%$ in a 3 -week feeding trial and were found to support a reasonable rate of egg production; excellent egg production was maintained on the diet containing the $10 \%$ increment of the amino-acids.

The work reported here was aided by a grant from the National Science Foundation.

Assistance from the following concerns is sincerely appreciated: Co-operative GLF Exchange, Ithaca, New York; Merck Sharp \& Dohme Research Laboratories, Rahway, New Jersey; A. E. Staley Manufacturing Company, Decatur, Illinois; Chas. Pfizer \& Company, Incorporated, Terre Haute, Indiana; Warner-Chilcott Laboratories, Morris Plains, New Jersey.

\section{REFERENCES}

Association of Official Agricultural Chemists (1955). Official Methods of Analysis, 8th ed., p. 805. Washington, D.C.: Association of Official Agricultural Chemists.

Benton, D. A., Harper, A. E., Spivey, H. E. \& Elvehjem, C. A. (1956a). Arch. Biochem. Biophys. 6o, 147. Benton, D. A., Harper, A. E., Spivey, H. E. \& Elvehjem, C. A. (1956b). Arch. Biochem. Biophys. 60 , I 56. Bird, H. R., Almquist, H. J., Cravens, W. W., Hill, F. W. \& McGinnis, J. (1954). Publ. nat. Res. Coun., Wash., no. 301.

Block, R. J. \& Weiss, K. W. (1956). Amino Acid Handbook. Springfield, Ill.: Charles C. Thomas.

Carpenter, K. J., Duckworth, J. \& Ellinger, G. M. (1954). F. agric. Sci. 44, 340.

Cravens, W. W. (1948). Poult. Sci. 27, 562.

Elvehjem, C. A. (1956). Cereal Sci. Today, r, 162.

Fisher, H. \& Johnson, D. Jr. (1956). F. Nutr. 60, 26 I.

Ingram, G. R., Cravens, W. W., Elvehjem, C. A. \& Halpin, J. G. (1951). Poult. Sci. 30, 462.

Johnson, D. Jr. \& Fisher, H. (1956). F. Nutr. 6o, 275 .

Machlin, L. J. (1955). Poult. Sci. 34, 984.

Miller, E. C., Sunde, M. L., Bird, H. R. \& Elvehjem, C. A. (1954). Poult. Sci. 33, 1201.

Miller, L. L. (1944). F. biol. Chem. 152, 603.

Mitchell, H. M. (1950). In Protein and Amino Acid Requirements of Mammals, p. I. [A. A. Albanese, editor.] New York: Academic Press Inc.

Nasset, E. S. (1957). F. Nutr. 6r, 555 .

Rose, W. C., Eades, C. H. Jr. \& Coon, M. J. (1955). F. biol. Chem. 216, 225.

Swendseid, M. E. \& Dunn, M. S. (1956). F. Nutr. 58, 507.

Thornton, P. A., Blaylock, L. G. \& Moreng, R. E. (1957). Poult. Sci. 36, 552.

Vanstone, W. E., Maw, W. A. \& Common, R. H. (1955). Canad. F. Biochem. Physiol. 33, 891. 